Article

\title{
Wall Vegetation Characteristics of Urban and Sub-Urban Areas
}

\author{
Emrah Yalcinalp ${ }^{1, *}$ and Alperen Meral $^{2}$ \\ 1 Department of Landscape Architecture, Faculty of Forestry, Karadeniz Technical University, \\ Trabzon 61080, Turkey \\ 2 Department of Landscape Architecture, Faculty of Agriculture, Bingol University, Bingol 12000, Turkey; \\ alperenmeral@bingol.edu.tr \\ * Correspondence: yalcinalp@ktu.edu.tr
}

Received: 20 July 2017; Accepted: 18 September 2017; Published: 22 September 2017

\begin{abstract}
Unfortunately, we live in a greedy little world and horizontal areas are often too expensive to leave to nature on them. Therefore, creating gardens on vertical surfaces of urban areas has recently been very important to supporting sustainability because these surfaces are still found to be commercially useless compared with green areas which are generally under pressure from commercial demands and politics. However, these artificial vertical green surfaces are still too far from being common, while too many ordinary walls are spontaneously covered with vegetation already. In this study, we try to address the dynamics of wall vegetation as it has a great potential to make the cities more sustainable. Totally 70 walls (35 in urban and 35 in sub-urban areas) in Trabzon city were examined regarding their ecological, physical and vegetation characteristics. Having identified 1540 plant samples collected from the walls during a year-round intensive field study, we performed statistical analyzes to enumerate the wall vegetation depending on the ecological characteristics; to evaluate if there are different wall vegetation compositions in urban and sub-urban areas; and finally to evaluate growth conditions and basic challenges for the wall vegetation.
\end{abstract}

Keywords: green wall; wall vegetation; vertical garden; habitat analogue; urban sub-urban areas

\section{Introduction}

Land use change is the driver that has the largest global impact on biodiversity worldwide [1]. Since human settlement is a prevailing source of land use change all over the world [2], rapid urbanization has become a great threat to natural resources in recent years. Half of the world's population dwells in urbanized areas, which cover approximately $2 \%$ of the Earth's terrestrial surface $[3,4]$. Moreover, more buildings and infrastructure are supposed to be constructed in the next 50 years than have been built throughout human history [5,6], which will possibly make the problem much worse in urban areas within a few decades, while they are already characterized by low biodiversity, the introduction of non-native species, and simplified species composition and community structures with extensive degradation of natural habitats and attendant biota $[4,7]$.

Many ecological studies however treat urban areas as homogeneous entities and combine all anthropogenic factors into one aggregated variable, while urbanization is actually multidimensional and highly variable across time and space [8]. Similarly, most of the studies examining the composition of local species consider urban areas as one land use type, without categorizing it in subtypes according to the density, structure or function of built-up areas. This although $[9,10]$ have showed that plants in urban areas can find some specific isolated places which show significant differences to the general character of the area, mentioning some plants that do not always have to be in the same conditions even within homogenous-looking small urban areas, owing to such artificial structural elements as harbors, revetments, walls, etc. 
As for walls, composed of brick, stone, mortar or concrete, they are widely distributed in the urban ecosystem [3]. However, still very limited studies have focused on the differences in vegetation composition and their proportions on the surfaces of walls depending on the ecological characteristics of their locations. Vegetation can however be easily affected by the near environment. Furthermore, some plant species are favored by urban environments and this situation has often been mentioned by some studies on the comparison of species traits of flora between urban and open rural landscapes [9,11-13]. In general, urbanization is a process that changes flora through a series of filters, which influence habitat availability, the spatial arrangement of habitats, the pool of plant species and the evolutionary selection pressures on populations persisting in urbanized areas [14]. Despite the massive and pervasive human perturbation, urban ecosystems can provide a variety of substrata for colonization by vegetation and wildlife [3]. There is no doubt that walls are a characteristic habitat found in human settlements and their surroundings [15]. As soon as these artificial vertical habitats were formed, nature's cliff-hangers would begin to colonize the vacant niches [16]. While vertical surfaces—especially walls—carve lands from hill slopes in urban areas have become much beset, owing to new instruction technologies, this logically made these vertical surfaces very essential platforms to make important contributions to the biodiversity of urban areas.

As urban areas have been under real commercial and residential pressure for decades, lack of green areas in many urban parts of the world has been a common issue among politicians, scientists, NGOs and finally residents. In spite of the fact that urban areas have to possess more green areas so that the people living in them can be physically and psychologically healthier, it is not that easy to find "suitable" places to create these areas since many horizontal surfaces are too costly for this kind of "economically valuable" part of the city. Therefore, vertical greening in urban areas became a popular way to have some nature in cities while these vertical surfaces-at least so far-have no active commercial or residential economic value compared with horizontal surfaces in the urban areas of the world and they are good abodes for spontaneous or synanthropic plant species. Especially masonry is ecologically quite similar to nature's rocky cliffs [17]. Supporting this idea, many researchers claim they have some common features such as bare stone surfaces and cracks, soil, humus, moisture and available space so that wall vegetation can attach and survive $[7,18,19]$.

This study focuses on the wall vegetation compositions shaped by ecological parameters both in urban and in sub-urban areas. Since the creation of more vertical green surfaces in urban areas strongly depends on their ecological and economic suitability, this study aims to assess the differences between the wall vegetation that can spontaneously survive in urban and in sub-urban areas; and the basic parameters affecting them and their compositions so that this mechanism could be adapted to create more suitable green surfaces in order to increase ecological quality in urban areas in the near future. To make this possible, analysis of the detailed information gleaned in this study helps (1) to enumerate the wall vegetation depending on the ecological characteristics; (2) to evaluate if there are different wall vegetation typologies in urban and sub-urban areas; (3) to evaluate growth conditions and basic challenges for the wall vegetation; and (4) to discuss how to use this information to make cities ecologically better while artificial green surfaces in urban areas are still expensive, especially because of the high requirements of artificially used green wall plants.

\section{Material and Method}

\subsection{Study Area}

The study focuses on the wall vegetation which spontaneously grows on the randomly selected walls in the urban and sub-urban parts of Trabzon in the northeastern Black Sea region of Turkey $\left(40^{\circ} 33^{\prime} \mathrm{N}-41^{\circ} 07^{\prime} \mathrm{N} ; 37^{\circ} 07^{\prime} \mathrm{E}-40^{\circ} 30^{\prime} \mathrm{E}\right.$ ) (Figure 1). In spite of the fact that the city of Trabzon has had another administrative status for a few years, the former administrative boundaries used by the municipality were evaluated to determine urban and sub-urban areas in this study. Due to the harsh and steep environmental conditions of the region, cutting slopes into flights of platforms to create 
settlements was very common, which makes Trabzon a kind of "city of the walls". The city covers an area of approximately $4.685 \mathrm{~km}^{2}$ and has a population of about 758.237 inhabitants, making it the second largest principal city in the region [20]. The city is within the A8 of the grid system created by $[21,22]$ and the annual mean rainfall is about $760 \mathrm{~mm}$, while the mean temperature is about $14.6^{\circ} \mathrm{C}$. The monthly mean temperature ranges from $7.3^{\circ} \mathrm{C}$ in January and from 13 to $23.1^{\circ} \mathrm{C}$ in August.

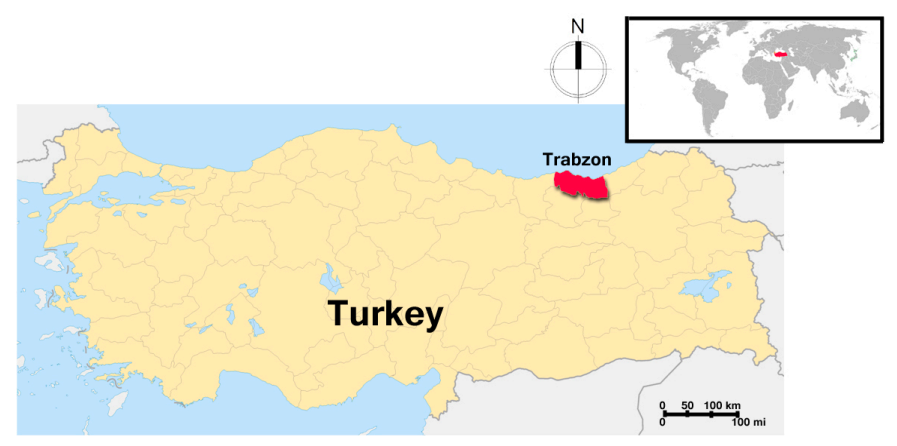

Figure 1. Study area.

\subsection{Sampling Procedure}

A total of 70 walls (35 in urban and 35 in sub-urban areas) were randomly selected with the only requirement being that vegetation was relatively present. While the walls in the urban parts of the city are logically concentrated in the city center, we had to travel towards both the west and the east of the city center up to $50 \mathrm{~km}$ to select the walls in the sub-urban parts. Since the plants growing only on the vertical surfaces of the walls were not able to define the green parts of the walls visually and ecologically, and since walls are quite good at creating small niches showing very different ecological microhabitat characteristics even within a few meters, while this study focuses on the walls as habitats, each wall was divided into three microhabitats: from $1 \mathrm{~m}$ behind the wall (microhabitat $\mathrm{I} / \mathrm{crest}$ ), the wall surface (microhabitat II), and finally up to $1 \mathrm{~m}$ in front of the wall (microhabitat III/foot) so that all the green supporters of the walls could be evaluated in the study (Figure 2). Each plant species within each microhabitat on every wall was separately collected. While trees, shrubs, herbs and grasses were collected, a few non-vascular components including some lichens and mosses were ignored; a total of 1540 plant samples collected and all the species were identified in the laboratory, using KATO (Herbarium of the Forestry Faculty, Karadeniz Technical University) specimens and some botanical sources [23]. The taxa names given in this study conform to those of [21,22].

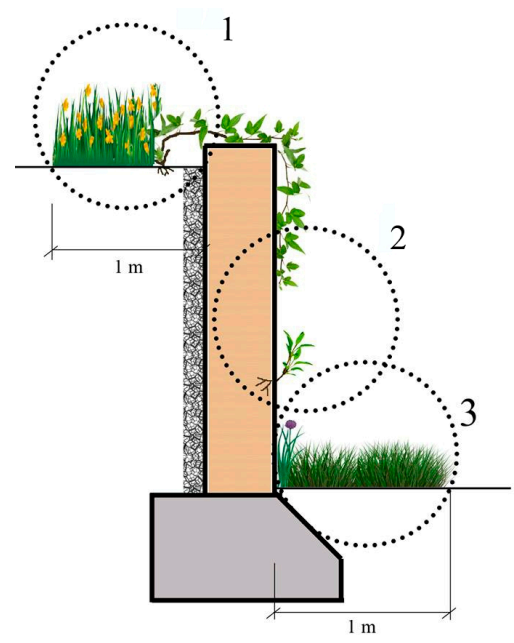

Figure 2. Microhabitats in which the plants were collected. 
In addition to plant species presence and abundance in different wall microhabitats, the basic wall parameters including ecological and physical characteristics were also recorded (Table 1).

Table 1. Set of basic parameters used for the characterization of the walls.

\begin{tabular}{|c|c|c|c|}
\hline Basic Wall Parameters & Variables & Description/Unit & Assessment Method \\
\hline \multirow{5}{*}{ Ecological } & Aspect & Cardinal directions $(\mathrm{N}, \mathrm{S}, \mathrm{E}, \mathrm{W})$ & GPS/Map/Measured on site \\
\hline & $\begin{array}{c}\text { Daily average direct } \\
\text { sunshine period (DADSP) }\end{array}$ & Hour $(0<2<4<6<8<10+)$ & Stopwatch/Measured on site \\
\hline & Anthropogenic effect & $\begin{array}{l}\text { Level (none-slightly-moderate- } \\
\text { dominate) }\end{array}$ & $\begin{array}{l}\text { Observation/Visual } \\
\text { assessment }\end{array}$ \\
\hline & Land use at foot & $\begin{array}{c}\text { Function (Pedestrian circulation, } \\
\text { water runnel) }\end{array}$ & $\begin{array}{l}\text { Observation/Visual } \\
\text { assessment }\end{array}$ \\
\hline & Land use at crest & $\begin{array}{l}\text { Function (Road or settlement, Green } \\
\text { area, Agricultural field) }\end{array}$ & $\begin{array}{c}\text { Observation/Visual } \\
\text { assessment }\end{array}$ \\
\hline \multirow{9}{*}{ Physical } & Location & Coordinate (Urban, Sub-urban) & GPS/Map/Measured on site \\
\hline & Age & Year $(-<5<10<+)$ & Interview/Office work \\
\hline & Length & Meter $(-<50<100<+)$ & $\begin{array}{l}\text { Laser distance meter/ } \\
\text { Measured on site }\end{array}$ \\
\hline & Inclination & $\begin{array}{c}\text { Gradient } \\
\text { (Positive-perpendicular-negative) }\end{array}$ & $\begin{array}{l}\text { Incline meter/ } \\
\text { Measured on site }\end{array}$ \\
\hline & Altitude & Meter $(-<100<200<300<400<+)$ & GPS/Measured on site \\
\hline & Wall material & Type (Concrete, stone, briquette) & $\begin{array}{c}\text { Observation/ } \\
\text { Visual assessment }\end{array}$ \\
\hline & Main material at crest & Permeable/Impermeable to water & $\begin{array}{c}\text { Observation/ } \\
\text { Visual assessment }\end{array}$ \\
\hline & Sealing of joints & Yes, No & $\begin{array}{c}\text { Observation/ } \\
\text { Visual assessment }\end{array}$ \\
\hline & Wall function & Type (Retaining, border) & $\begin{array}{c}\text { Observation/ } \\
\text { Visual assessment }\end{array}$ \\
\hline \multirow{4}{*}{ Vegetation } & Species richness & Number of species on the walls & Measured on site/KATO \\
\hline & Vegetation coverage & Type (Coverage ratio on wall surfaces) & $\begin{array}{l}\text { Measured on site/Visual } \\
\text { assessment/Office work }\end{array}$ \\
\hline & $\begin{array}{l}\text { Vegetation (Microhabitat I, II, } \\
\text { III) cover on surface of } \\
\text { the walls }\end{array}$ & Percentage & $\begin{array}{l}\text { Measured on site/ } \\
\text { Office work }\end{array}$ \\
\hline & $\begin{array}{c}\text { Wall Vegetation } \\
\text { (Microhabitat II) cover on } \\
\text { surface of the walls }\end{array}$ & Percentage & $\begin{array}{l}\text { Measured on site/ } \\
\text { Office work }\end{array}$ \\
\hline
\end{tabular}

A year-round intensive field study was conducted in 2014 to gauge all the parameters mentioned in the table above. Some variables were very difficult to evaluate, such as the anthropogenic effects on wall surfaces, which required learning if there were annual and effective vegetation removal by officials and public (dominate anthropogenic effect), irregular vegetation removal by officials (moderate anthropogenic effect), irregular and inefficacious vegetation removal by public (slightly anthropogenic effect) and clearly no vegetation removal (none), by asking General Directorate of Highways, the municipality and the local people in the study area. A total of 70 walls and 210 microhabitats belonging to them were assessed. The wall locations were pinned by a Garmin GPSmap and panoramic photos were taken with a Sony A6000 digital camera to create an ID card for each wall. Then a table with every parameter in it was put on the ID cards to create the first step in the wall vegetation form. The basic wall parameters mentioned above and some others that were added after identifying the plant species—such as life forms classification by Raunkiaer [24], which was followed and improved by Ellenberg and Mueller-Dombois [25]—were created with Microsoft Excel and then those tables were statistically performed with SPSS for Windows. 


\subsection{Data Analysis}

This study determined 70 different walls, half of which were in urban parts of the city while the other half were in sub-urban areas, in the province of Trabzon, and the vegetation that occurs on these walls. Our statistical analyses showed the occurrence rate of the wall vegetation that grows spontaneously in the study field. The study also examined the relationships between the diversity of these plants and the factors that are supposed to have an important impact on their habitat. In this study, the basic wall parameters were set to determine the walls' ecological, physical and vegetation characteristics in the urban and sub-urban parts of the city (Table 1).

All the data gleaned in the study were initially analyzed using the Microsoft Office Excel program. After identifying the wall vegetation species, tabular data were prepared for further analysis. First, the physical characteristics of the walls were evaluated to understand if there are main differences or similarities between the walls in urban and the walls in sub-urban areas, or any further specific character belonging to the walls in any group. Afterwards, the identified plant species were analyzed to see their life forms [24], whether they were native [21,22], families, and occurrence.

The data analysis was based on the abundance and presence of various vegetation types and habitat variables all over the selected walls. Habitat variables were initially compared by the Pearson correlation test. In this study, the correlation coefficient $>0.7$ was adopted as the threshold for strongly correlated variables though [3]; the correlation coefficient $>0.6$ is already supposed to be strong enough to make most statisticians happy [26]. To be able to identify the habitat variables which affect the combinations in vegetation occurrence (species richness and vegetation coverage on the walls) multiple regression analysis was performed using SPSS 23 licensed by Karadeniz Technical University.

\section{Research Findings}

\subsection{The Walls}

Trabzon is hilly. As the center of the region, this extremely compact city often needs to build walls to accommodate the roads, buildings and several other main functions by shaping the hill slopes. Retaining walls are often classified in terms of their relative mass, flexibility, and anchorage condition [27], and because of its geomorphological characteristics, Trabzon is a city in which one can see different types of walls in urban and sub-urban parts of the city. While stone walls are intuitively known to be hostile to vegetation establishment due to verticality, lack of substrate, inadequate nutrient and moisture supply and dominance by sterile stone surfaces, masonry retaining walls often offers opportunities for plant life [3]. In spite of the fact that it is quite easy to observe that concrete walls, one of the most common wall types in the research area, have big challenges for plant life; nature often finds a way to send its representatives even to the most difficult wall surfaces, using narrow gaps between blocks, joints and cracks that surprisingly allow many ready-for-fight plants to send their roots into the wall, which are filled with a mixture of different substrates such as soil, sand and dust (Figures 3 and 4 ).

Walls in the study area were mainly constructed from pre-fabricated concrete elements $(67.1 \%)$ while the rest $(32.9 \%)$ are made of stone or brick. However, concrete walls were obviously more common in urban parts $(82.8 \%)$ compared with the sub-urban $(51.4 \%)$. The walls are mostly vertical $(93.3 \%)$ and older than 10 years $(56.7 \%)$. The most common land use functions were the circulation of vehicles and pedestrians at the foot $(91.7 \%)$ and residential (35\%) at the crest. As with the joints that are the main spaces for plants to hold, most of the walls had mortared joints $(65 \%)$ while only $28.3 \%$ of the walls had no joint and the rest $(6.7 \%)$ had open joints. Most of the walls (71.7\%) had no drainage holes, which is one of the main ways that water leaks through wall surfaces and bring life for plants. Retaining walls were the most common walls $(83.3 \%)$, while the rest $(16.7 \%)$ were just borders in the study. Walls in the study area mainly face north (45\%), followed by east (31.7\%), west $(18.3 \%)$ and south (5\%). 


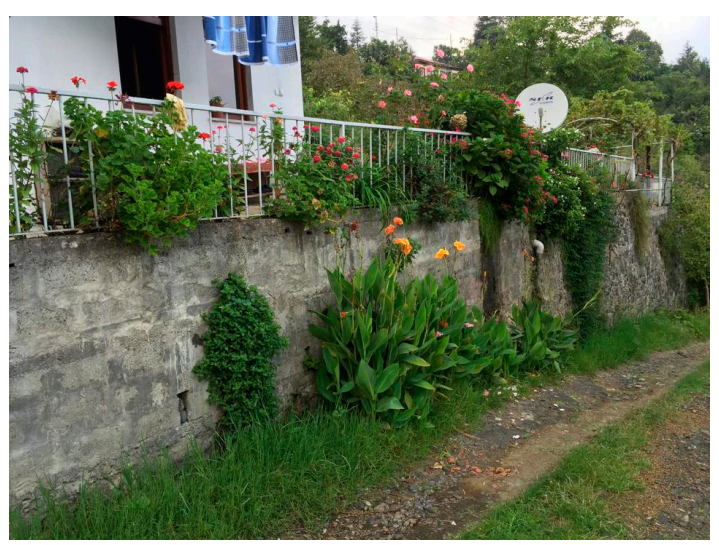

Figure 3. A typical wall that clearly represents microhabitats I-II and III.

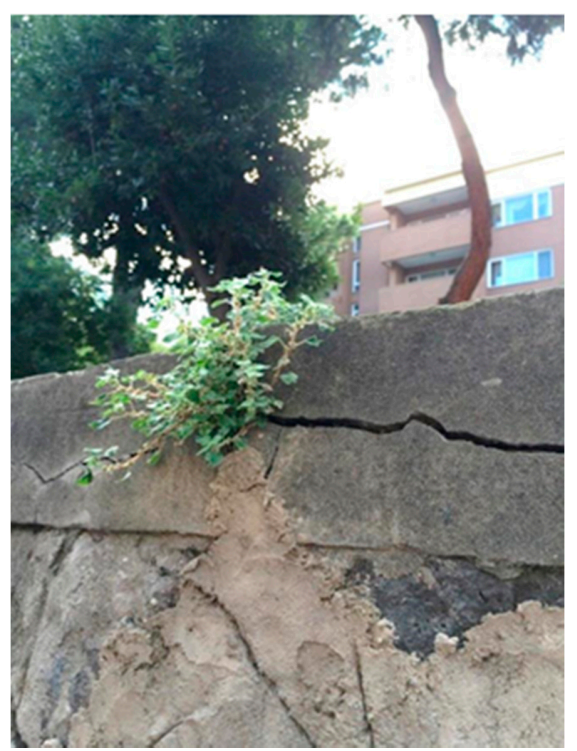

Figure 4. A signature species, Parieteria judacia, sending its roots into the wall via an unexpected crack in the wall.

Despite there being no official or unofficial record that we have found so far reporting any wall damage by vegetation in the city, it is not hard to say that people generally believe plants on a wall can damage its solidity. As a result of this generally well-known belief and some conflicts between vegetation and buildings, pavements and some other artificial structures-like those reported by [28-31] - it is seldom possible to see wall vegetation being removed from the wall surfaces in the city. However, the number of wall trees is known to be tiny in comparison with the hundreds to thousands of tons of wall materials, and this vegetation could be ecologically very useful, so that maintenance or repair work should be phased over several years to allow some regeneration of wall plants after consolidation from as-yet untouched sections, wherever possible [3,32].

\subsection{The Wall Vegetation}

All the wall vegetation, including microhabitat I, II and III in the research area, has 196 species in 69 families, 40 of which (57.97\%) is represented by only one species. The most dominant family is Asteraceae and it has 30 species. As for the urban and sub-urban areas, we found 119 species in 52 families in the urban areas, while this was 131 species in 49 families in the sub-urban parts. While 
Asteraceae is still the most dominant family in the both urban and sub-urban areas, it has 16 species in the urban areas and 23 in the sub-urban areas.

Another important vegetation definition parameter, life forms, also varies in the research area. The research area totally possesses six different life forms. While 81 species out of 196 are Hemicryptophyts $(42 \%)$, other life forms and the number of the plant species within them are Phanerophyt (45 species; $23 \%$ ), Crytophyt (33 species; $16 \%$ ), Chamaephyt (28 species; $14 \%$ ), Geophyt (five species; $3 \%$ ) and Therophyt (four species; $2 \%$ ) (Figure 5).

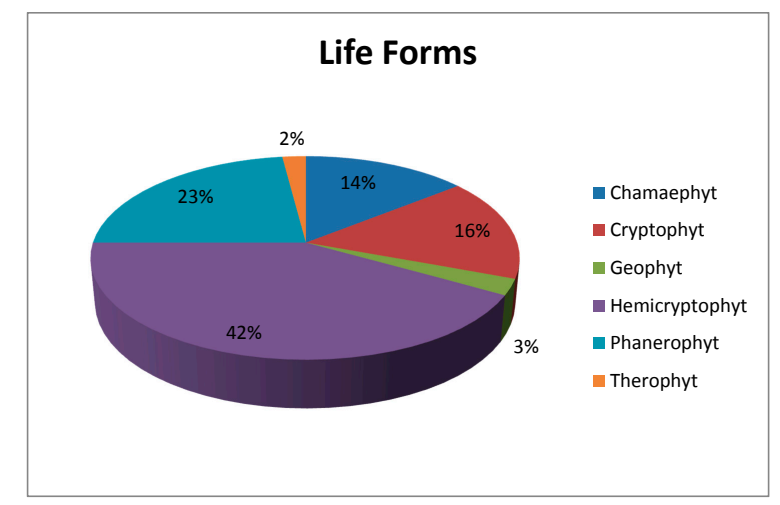

Figure 5. Life forms of the plant species found on the walls.

In the urban and sub-urban areas, some specifically artificially conditioned areas, just like walls, were colonized only by plant species with specific adaptations for development and reproduction [33]. Furthermore, the diversity of the flora found on the walls is known to vary depending on many different criteria such as geography [3], plant characteristics [34] and even the history of the cities [35]. Herbaceous plants are generally considered the most common among wall vegetation all over the world. For example, while a study reported $77.6 \%$ of the most common higher plants were herbaceous on the walls of several towns in the Mediterranean [34], the same rate was around 93\% on the walls of Sao Paulo, Brazil [35]. For comparison, this study similarly founded 77\% herbaceous plant on the walls in both urban and sub-urban areas. However, as one of the most logical arguments to prove that studying urban and sub-urban areas separately was a good idea, the herbaceous plant rate was only $1.8 \%$ in the sub-urban areas, which means that locations even within a city might have quite different wall vegetation components. While Ficus carica was the only woody plant species we found on the walls of the sub-urban areas, the other woody plant species Corylus avellana, Robinia pseudoacacia, Prunus sp. and finally Ficus carica again were seen on the walls of the urban areas.

As for native plants, 129 species (66\%) out of 196 are known to be native to Trabzon, while the rest (67 species out of 196, which means $34 \%$ ) seem to be introduced to the city (Figure 6).

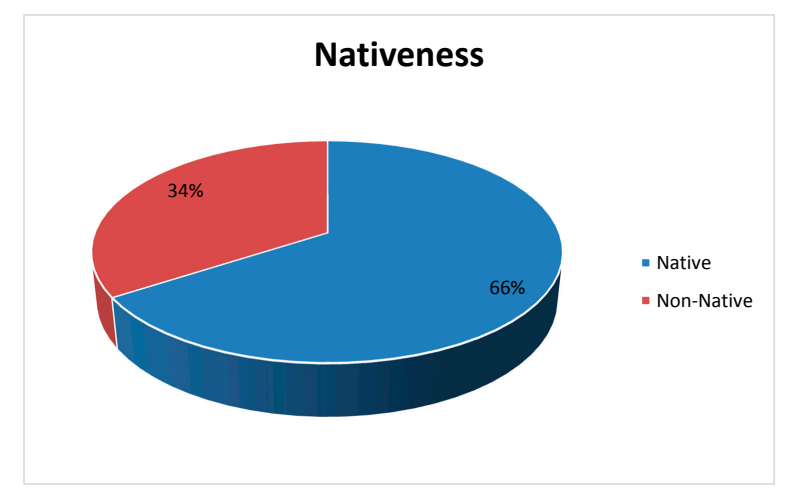

Figure 6. Share of native plant species found on the walls. 
When focusing on the plants growing in the microhabitats II, which have literally been called "wall vegetation" by many previous researchers, as the plants directly attach themselves to the wall by sending their roots into it, it is still possible to see some interesting results. While Parietaria judaica is the most common (40\%) species on the walls in the urban areas-confirming its common name "pellitory of the wall" - the same plant species, surprisingly, is hardly seen on the walls in the sub-urban areas, with a rate of $10 \%$ (Figures 7 and 8 ). The signature wall plant, however, is still very popular in the scientific world not only owing to its expansive ability to grow on the walls in urban environments, but also the allergenic potential of its pollens.

Only one found species on the wall surfaces in the urban areas (3.2\%) is non-native to Trabzon city. This would have been seen as "ordinary", if we had not found that $26.4 \%$ of the wall vegetation in the semi-urban areas was non-native, mainly because of the introduced plant species especially found in drainage holes on the surface of the walls. These "alien" species were probably brought by people attempting to create attractive walls in semi-urban parts, or they were just escapees from the surrounding ornamental gardens, as we often saw that people who lived very close to the randomly selected walls were keeping the same species in their private gardens. Campsis radicans, Pelargonium hybrida, Philadelphus coronaries, Ligustrum japonica and Beta vulgaris are the most common species within this group. Although the semi-urban areas generally represented more naturalistic ecological characteristics compared with the urban parts, the people living in semi-urban areas were likely to have more time to deal with the environment in which they were living, and the walls in the urban parts were clearly more prone to artificial vegetation clearing by the municipality, especially on the fatal parts, such as drainage holes.

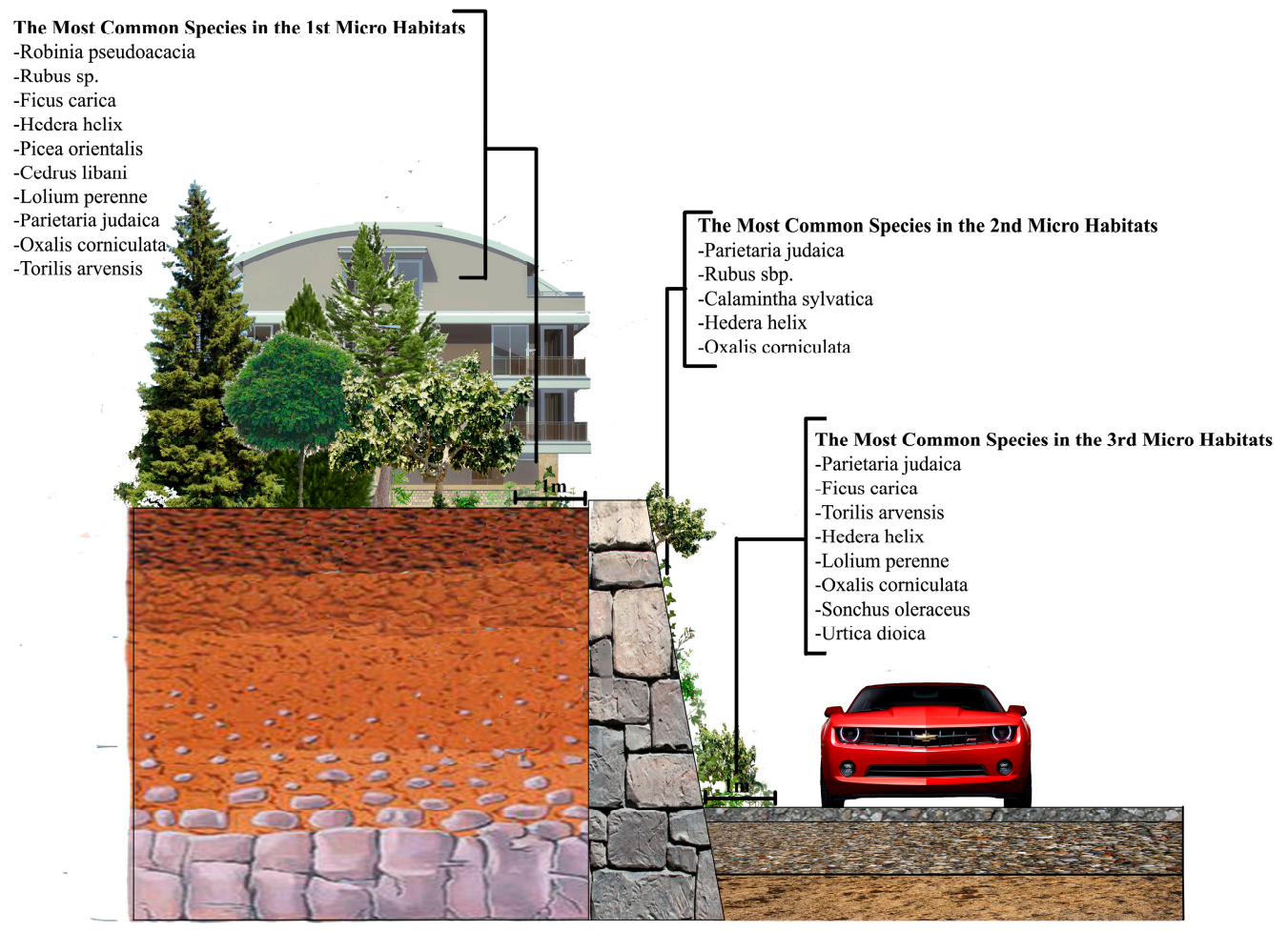

Figure 7. Typology of the walls as habitat in the urban areas: The most common species $(>10 \%)$ at crest: Robinia pseudoacacia; on the wall: Parietaria judacia; at foot: Parietaria judacia. Land use at crest: Residential (53.3\%); Land use at foot: Road (96.7\%). 


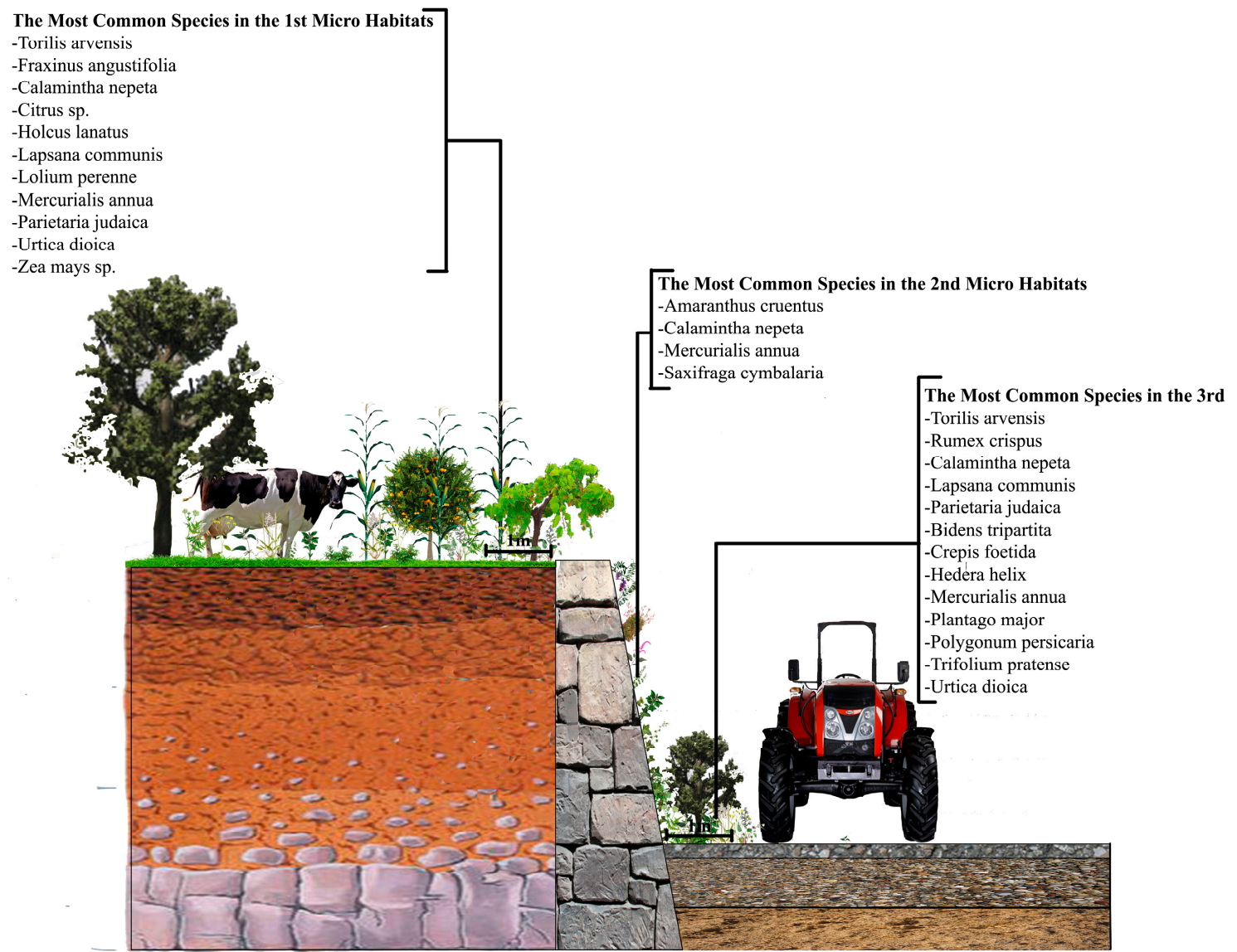

Figure 8. Typology of the walls as habitat in the sub-urban areas: The most common species ( $>10 \%)$ at crest: Torilis arvensis; on the wall: Amaranthus cruentus; at foot: Torilis arvensis. Land use at crest: Agriculture (64.6\%); Land use at foot: $\operatorname{Road}(90 \%)$.

\section{Discussion and Results}

When examining the relations between vegetation characteristics and habitat variables, six significant factors were identified (Table 2). Factor one involves the location of the walls, which means whether the wall is in the urban or sub-urban parts of the research area. Factor two is the coverage on the walls by plants growing in the first, second and third microhabitats, which means that these plants do not have to grow on the vertical surface of the walls, they can climb from the foot or drop from the crest. Factor three involves wall vegetation coverage, which means the coverage by the plants only growing on the vertical surfaces of the walls. Factor four is species richness, meaning the number of plant species collected from the walls. Factor five is land use type at the crest (or behind the wall, in other words) and, finally, factor six is the sealing of the joints, which determine whether the wall surfaces have any cracks, joints or any other small niches so that plants can attach, or whether these were already artificially filled. In spite of the fact that some important factors were directly or indirectly mentioned in previous studies, such as surface moisture, aspect, wind, etc. [3,15,16,34,36,37], we could not find any statistically strong argument between them and wall vegetation occurrence. 
Table 2. Correlate analysis for study area.

\begin{tabular}{ccccccc}
\hline & \multicolumn{7}{c}{ Correlations } \\
\hline & $\begin{array}{c}\text { Location of } \\
\text { the Walls }\end{array}$ & $\begin{array}{c}\text { Wall Vegetation } \\
\text { Coverage (2nd } \\
\text { Microhabitats) }\end{array}$ & $\begin{array}{c}\text { Species } \\
\text { Richness }\end{array}$ & $\begin{array}{c}\text { Land Use } \\
\text { at Crest }\end{array}$ & $\begin{array}{c}\text { Sealing of } \\
\text { Joints }\end{array}$ \\
\hline $\begin{array}{c}\text { Coverage on the Walls } \\
\text { by plants growing in } \\
\text { the 1st, 2nd and 3rd } \\
\text { microhabitats }\end{array}$ & \begin{tabular}{c} 
Pearson \\
\cline { 2 - 7 }
\end{tabular} & $0.724^{* *}$ & $0.765^{* *}$ & $0.508^{* *}$ & $0.704^{* *}$ & $-0.519^{* *}$ \\
\cline { 2 - 7 } & Sig. (2-tailed) & 0.000 & 0.000 & 0.000 & 0.000 & 0.000 \\
\hline & $\mathrm{N}$ & 70 & 70 & 70 & 70 & 70 \\
\hline
\end{tabular}

However, it is possible to say that the location of the walls has important effects on the coverage by plants, wall vegetation coverage and the species richness on the wall surfaces. According to this, the walls in the sub-urban areas have a higher coverage rate and more plant species on their surfaces than the ones in the urban areas. As with the sealing of joints (mortared joints and no joints), which clearly affect plant coverage on walls, it can be defined as an important factor keeping plants away from wall surfaces.

Although we could not find any correlation between surface moisture by sight, which is a well mentioned factor in previous studies, and any other factors regarding wall vegetation, another vital factor for wall vegetation, land use behind walls, shows a strong correlation with wall vegetation coverage. Land use behind walls or at the crest, as we mentioned in this study, is known to be one of the most important reasons for moisture availability, if it is not the most important. Especially naturally-vegetated fields behind walls provide a great source of moisture for the wall surfaces as they are the best areas for infiltration. When a wall has a well-vegetated field at the crest, it can gradually get water from the field even when there is no rainfall during long periods. Infiltrated rainwater soaking the soil behind walls supplies seepage out through weep holes and joints [16]. Cracks or joints are the other main ways for water to get to the surface. Apart from water, a well-vegetated field can fertilize walls because it naturally has a great deal of organic material, which is also an essential eutrophic outflow source for wall vegetation, which has great difficulty in creating strong root systems in such difficult and challenging habitats.

One of the most desirable results of the study was to see which habitat characteristics would affect the plant coverage and species richness on walls in the early stages of the study. To determine that, multiple regression analysis was performed (Tables 3-5).

Table 3. Model summary for study area.

\begin{tabular}{ccccc}
\hline \multicolumn{5}{c}{ Model Summary } \\
\hline Model & R & R Square & Adjusted R Square & Std. Error of the Estimate \\
\hline 1 & $0.771^{\text {a }}$ & 0.594 & 0.548 & 0.778 \\
\hline
\end{tabular}

Note: a Predictors: (Constant), Material, Isolation, DADSP (Daily average direct sunshine period), Species richness, Land use at crest, Material at crest.

Table 4. ANOVA test for study area.

\begin{tabular}{ccccccc}
\hline \multicolumn{7}{c}{ ANOVA $^{\mathbf{b}}$} \\
\hline & Model & Sum of Squares & df & Mean Square & F & Sig. \\
\hline \multirow{4}{*}{1} & Regression & 46.939 & 6 & 7.823 & 12.939 & $0.000^{\text {a }}$ \\
& Residual & 32.044 & 53 & 0.605 & & \\
& Total & 78.983 & 59 & & & \\
\hline
\end{tabular}

Notes: ${ }^{a}$ Predictors: (Constant), Material, Isolation, DADSP (Daily average direct sunshine period), Species richness, Land use at crest, Material at crest; ${ }^{b}$ Dependent Variable: Wall vegetation cover in the second microhabitats. 
It is clear that the most effective parameters that affect wall vegetation cover on the surface of walls are isolation on vertical surfaces, wall material, average direct sunshine duration on the wall and the main material at the crest (Table 5). First of all, plants need to find holding in vacant niches on the wall and to take nutrients and water, and a wall surface is not the easiest place to do this. The more vacant niches on the wall, the more nutrients and water are available for wall vegetation (Figure 9). In the study area, the most common joint material is mixed sand-lime-cement and no data is available to identify their rate. However, this material often loses its solidity due to climatic and other physical effects and lets wall vegetation take nutrients and water so that they can survive and grow. On the contrary, it is nearly impossible to see wall vegetation on concrete walls that have perfect and smooth surfaces if they do not have any drainage holes or an unexpected crack (Figure 10).

Table 5. Regression analysis for study area.

\begin{tabular}{|c|c|c|c|c|c|c|}
\hline \multicolumn{7}{|c|}{ Coefficients $^{a}$} \\
\hline & \multirow{2}{*}{ Model } & \multicolumn{2}{|c|}{ Unstandardized Coefficients } & \multirow{2}{*}{$\begin{array}{c}\text { Standardized Coefficients } \\
\text { Beta }\end{array}$} & \multirow{2}{*}{$t$} & \multirow{2}{*}{ Sig. } \\
\hline & & B & Std. Error & & & \\
\hline \multirow{7}{*}{1} & (Constant) & -1.541 & 0.755 & & -2.042 & 0.046 \\
\hline & Material & 0.476 & 0.228 & 0.225 & 2.092 & 0.041 \\
\hline & Isolation & 1.143 & 0.228 & 0.529 & 5.019 & 0.000 \\
\hline & DADSP & -0.331 & 0.103 & -0.303 & -3.203 & 0.002 \\
\hline & Species richness & 0.058 & 0.126 & 0.040 & 0.458 & 0.649 \\
\hline & Land use at crest & 0.040 & 0.171 & 0.023 & 0.233 & 0.817 \\
\hline & Material at crest & 0.967 & 0.349 & 0.271 & 2.771 & 0.008 \\
\hline
\end{tabular}

Note: ${ }^{\text {a }}$ Dependent Variable: Wall vegetation cover in the second microhabitats.

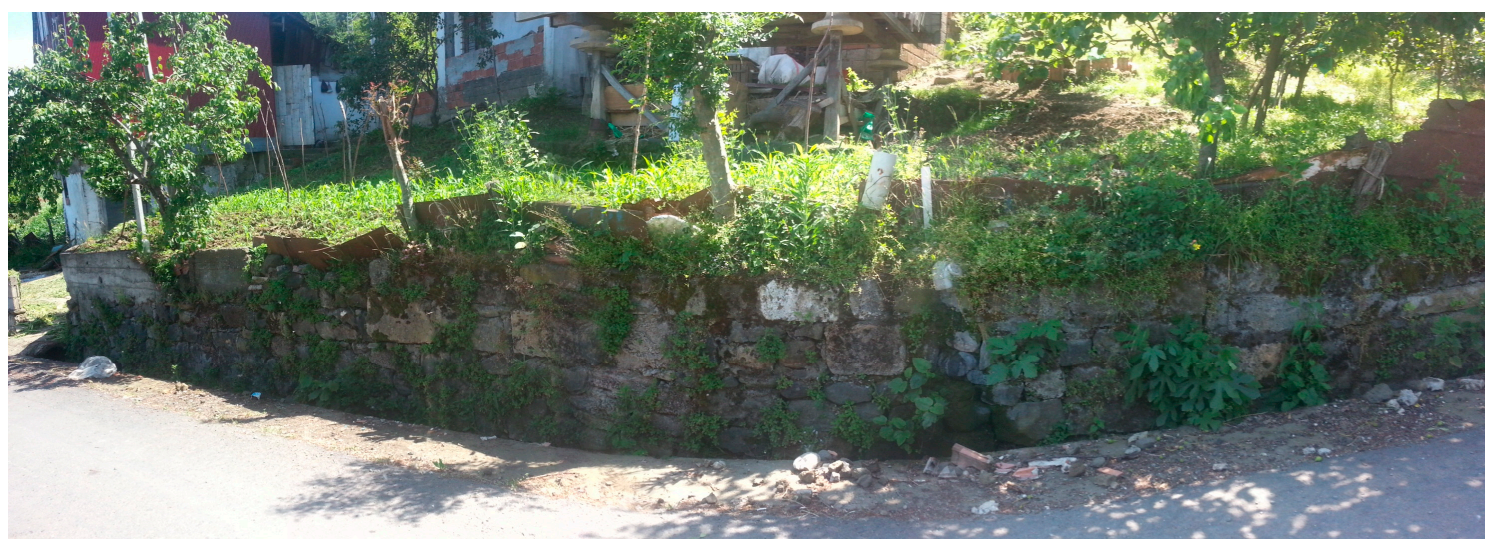

Figure 9. Relatively rich wall vegetation on a stone wall surface.

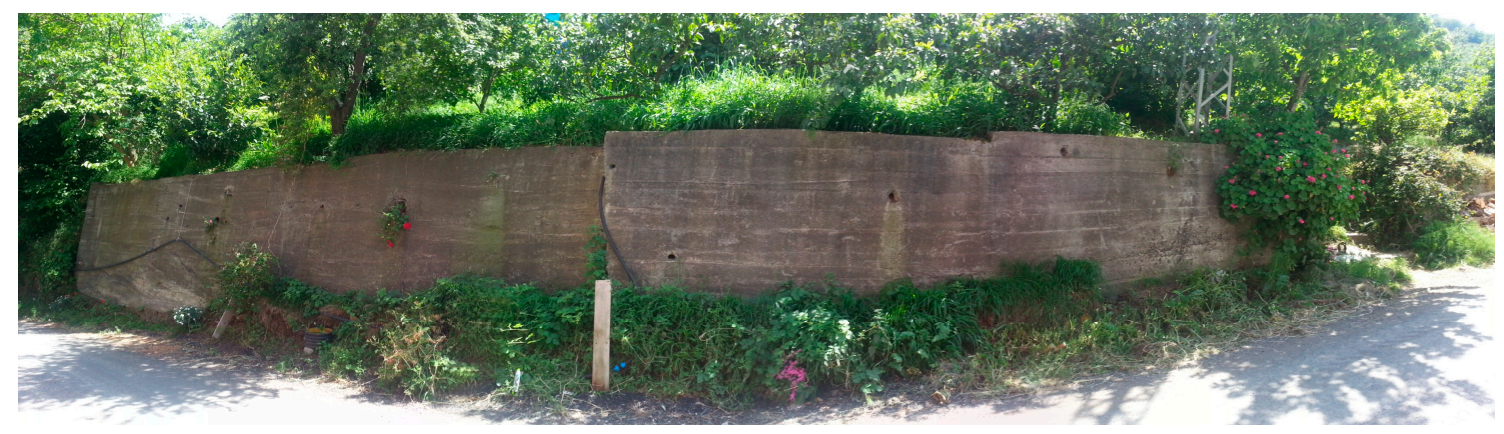

Figure 10. Very limited wall vegetation on a smooth concrete wall surface. 
Apart from precipitation mostly carried by wind to the surface of walls, the most valuable water resource for wall vegetation is the water stored by the mass behind the wall. As a result of this, land use and the material at the crest are vital for the wall vegetation. If water and nutrients can easily be stored and carried to the surface of the wall, these challenging mostly vertical areas might turn into appropriate habitats for the vegetation. While there are already limited water opportunities, high water loss risks due to wind and sunlight, and low nutrient potential on wall surfaces, the water stored at the crest and the nutrients in it are really important for the vegetation. We clearly found that the walls which have some land use types requiring impermeable surfaces such as asphalt, concrete etc., at the crest have relatively less vegetation on their vertical surfaces (Figure 11) while those which have more natural materials such as soil, meadows, pasture etc., at the crest have more, as they are capable of possessing more water and nutrients that can leak into walls so that the wall vegetation can make use of it (Figure 12).

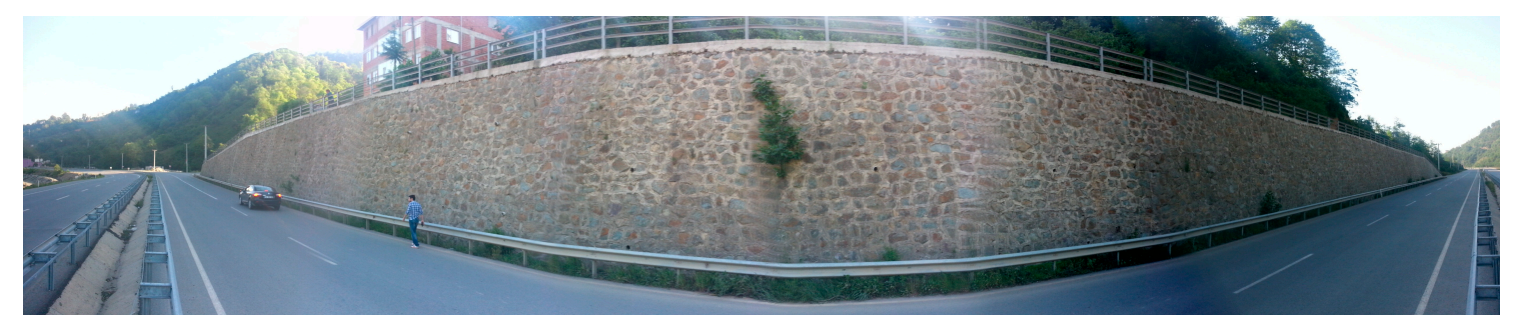

Figure 11. Wall vegetation (the main material is impermeable at the crest).

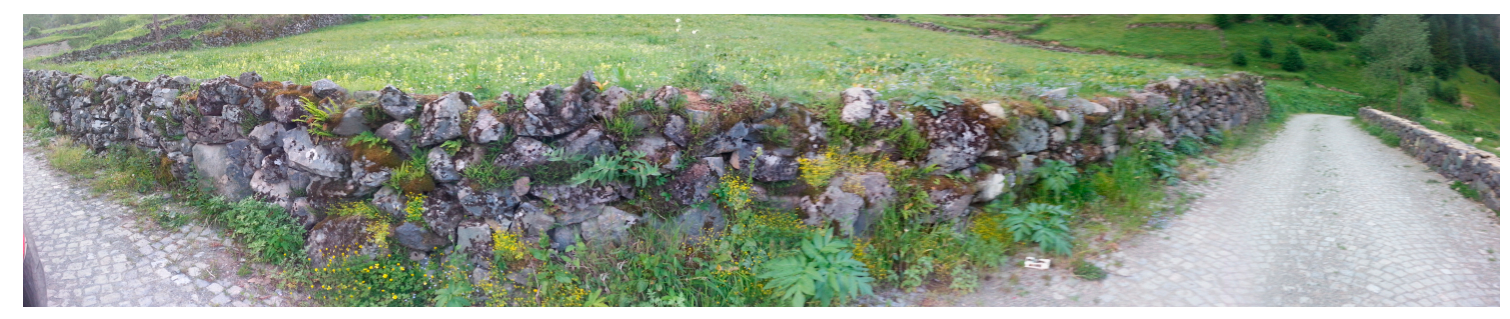

Figure 12. Wall vegetation (the main material is permeable at the crest).

The sealing of joints, another major parameter that affects wall vegetation, is often made to protect walls against water creating mortared joints, believing that this would make walls more durable. When there is no isolation on a wall, which means that wall has open joints, plants can easily attach themselves to the wall and water can easily leak through the wall surface. Since wind and sunlight generally make wall surfaces extremely dry and therefore poor in nutrients, these mortared joints can easily be defined as one of the most challenging characteristics for wall vegetation. Nevertheless, many plant species can still be seen on walls all in the study area (Table 6).

There is no doubt that we need more ecologically sustainable cities and therefore more green areas, and vertical gardens are really ideal for urban areas. Focusing on spontaneous wall vegetation in urban areas should be a good start to create economically and ecologically sustainable green walls for cities as they already exist in similar conditions. At this point, we believe that understanding wall vegetation dynamics will definitely help humanity to create healthier cities. 
Table 6. The most common plant species (only $>10 \%$ ) in the research area.

\begin{tabular}{|c|c|c|c|c|c|}
\hline \multicolumn{3}{|c|}{ Urban } & \multicolumn{3}{|c|}{ Sub-Urban } \\
\hline $\begin{array}{c}\text { 1st } \\
\text { Microhabitat } \\
\text { (Crest) }\end{array}$ & $\begin{array}{c}\text { 2nd } \\
\text { Microhabitat } \\
\text { (Wall Surface) }\end{array}$ & $\begin{array}{c}\text { 3rd } \\
\text { Microhabitat } \\
\text { (Foot) }\end{array}$ & $\begin{array}{c}\text { 1st } \\
\text { Microhabitat } \\
\text { (Crest) }\end{array}$ & $\begin{array}{c}\text { 2nd } \\
\text { Microhabitat } \\
\text { (Wall Surface) }\end{array}$ & $\begin{array}{c}\text { 3rd } \\
\text { Microhabitat } \\
\text { (Foot) }\end{array}$ \\
\hline $\begin{array}{c}\text { Robinia } \\
\text { pseudoacacia }\end{array}$ & $\begin{array}{c}\text { Parietaria } \\
\text { judaica }\end{array}$ & $\begin{array}{c}\text { Parietaria } \\
\text { judaica }\end{array}$ & Torilis arvensis & $\begin{array}{l}\text { Amaranthus } \\
\text { cruenthus }\end{array}$ & Torilis arvensis \\
\hline Rubus sp. & Rubus sp. & Ficus carica & $\begin{array}{c}\text { Fraxinus } \\
\text { angustifolia }\end{array}$ & $\begin{array}{c}\text { Calamintha } \\
\text { nepeta }\end{array}$ & Rumex crispus \\
\hline Ficus carica & $\begin{array}{c}\text { Calamintha } \\
\text { sylvatica }\end{array}$ & Torilis arvensis & $\begin{array}{c}\text { Calamintha } \\
\text { nepeta }\end{array}$ & $\begin{array}{c}\text { Mercurialis } \\
\text { annua }\end{array}$ & $\begin{array}{c}\text { Calamintha } \\
\text { nepeta }\end{array}$ \\
\hline Hedera helix & Hedera helix & Hedera helix & Citrus sp. & $\begin{array}{c}\text { Saxifraga } \\
\text { symbalaria }\end{array}$ & $\begin{array}{c}\text { Lapsana } \\
\text { communis }\end{array}$ \\
\hline Picea orientalis & $\begin{array}{c}\text { Oxalis } \\
\text { corniculata }\end{array}$ & $\begin{array}{l}\text { Lolium } \\
\text { perenne }\end{array}$ & Holcus lanatus & & $\begin{array}{c}\text { Parietaria } \\
\text { judaica }\end{array}$ \\
\hline Cedrus libani & & $\begin{array}{c}\text { Oxalis } \\
\text { corniculata }\end{array}$ & $\begin{array}{l}\text { Lapsana } \\
\text { communis }\end{array}$ & & $\begin{array}{c}\text { Bidens } \\
\text { tripartita }\end{array}$ \\
\hline $\begin{array}{l}\text { Lolium } \\
\text { perenne }\end{array}$ & & $\begin{array}{l}\text { Sonchus } \\
\text { oleraceus }\end{array}$ & $\begin{array}{l}\text { Lolium } \\
\text { perenne }\end{array}$ & & Crepis foetida \\
\hline $\begin{array}{c}\text { Parietaria } \\
\text { judaica }\end{array}$ & & Urtica dioica & $\begin{array}{c}\text { Mercurialis } \\
\text { annua }\end{array}$ & & Hedera helix \\
\hline $\begin{array}{c}\text { Oxalis } \\
\text { corniculata }\end{array}$ & & & $\begin{array}{c}\text { Parietaria } \\
\text { judaica }\end{array}$ & & $\begin{array}{c}\text { Mercurialis } \\
\text { annua }\end{array}$ \\
\hline \multirow[t]{4}{*}{ Torilis arvensis } & & & Urtica dioica & & Plantago major \\
\hline & & & Zea mays sp. & & $\begin{array}{c}\text { Polygonum } \\
\text { persicaria }\end{array}$ \\
\hline & & & & & $\begin{array}{l}\text { Trifolium } \\
\text { pratense }\end{array}$ \\
\hline & & & & & Urtica dioica \\
\hline
\end{tabular}

The remaining vegetated habitats in urban areas often contain low plant diversity as a result of erosion, trampling, pollution, invasion or the cultivation of a few non-native species and replacing the native species that are lost with the wide-spread presence of "weedy" non-native species. This can be defined as a great conservation challenge, while managing the large amount of residential vegetation in ways that promote native plants and animals could make a significant contribution to conservation [6]. Therefore, it can be said that green walls are supposed to support urban areas ecologically, and using some invasive or at least popular exotic plant species only because they can survive in the difficult conditions of wall ecology might not be logical or sustainable, even if they seem to create an attractive green wall surface. The use of native species is ideal to support biodiversity and they are generally the best ecosystem services providers, it would be great to use them on green walls as much as possible. Plus, even the non-native plant species that we found in this study make a contribution to urban ecosystems as they were already able to survive on the wall surfaces spontaneously. While the main purpose of humanity should be to create more sustainable environments by paying less ecologically and economically, there is no doubt that work on sustainable green wall systems should pay more attention to wall vegetation characteristics to reach the ideal, artificial green walls is the best way to follow both in urban and sub-urban areas.

Acknowledgments: This research was designed as a part of a master thesis of which the title is Wall Vegetation in Urban and Rural Areas Regarding Landscape Architecture and Their Ecological Characteristics, which was supervised by Emrah Yalcinalp and written by Alperen Meral in Institute of Natural Sciences of Karadeniz 
Technical University. We are thankful to our colleague Sefa Akbulut for his great contribution to the identifying of the plant species collected in the study area.

Author Contributions: All authors conceived and designed the article. Yalcinalp and Meral assembled the database, conducted the analysis and wrote the article. Yalcinalp revised the various drafts and supervised the research.

Conflicts of Interest: The authors declare no conflict of interest.

\section{References}

1. Vitousek, P.M.; Mooney, H.A.; Lubchenko, J.; Melillo, J.M. Human domination on Earth's ecosystems. Science 1997, 277, 494-499. [CrossRef]

2. United Nations Centre for Human Settlements. An Urbanizing World: Global Report on Human Settlements; Oxford University Press: Oxford, UK, 1996.

3. Jim, C.Y.; Chen, W.Y. Habitat effect on vegetation ecology and occurrence on urban masonry walls. Urban For. Urban Green. 2010, 9, 169-178. [CrossRef]

4. Grimm, N.; Grove, J.M.; Pickett, S.T.A.; Redman, C.L. Integrated approaches to long-term studies of urban ecological systems. Bioscience 2000, 50, 571-584. [CrossRef]

5. Orr, D.W. The Nature of Design: Ecology, Culture, and Human Intention; Oxford University Press: Oxford, UK, 2002.

6. McKinney, M.L. Urbanization, biodiversity and conservation. Bioscience 2002, 52, 883-890. [CrossRef]

7. Lundholm, J.T.; Marlin, A. Habitat origins and microhabitat preferences of urban plant species. Urban Ecosyst. 2006, 9, 139-159. [CrossRef]

8. Alberti, M.; Marzluff, J.M.; Bradley, G.; Ryan, C.; Shulenberger, E.; Zumbrunnen, C. Integrating humans into ecology: Opportunities and challenges for studying urban ecosystems. Bioscience 2003, 53, 1169-1179. [CrossRef]

9. Godefroid, S.; Koedam, N. Urban plant species patterns are highly driven by density and function of built-up areas Sandrine. Landsc. Ecol. 2007, 22, 1227-1239. [CrossRef]

10. Acar, C.; Kahveci, H.; Palabas, S. The analysis and assessment of the vegetation on coastal revetments: The case of Trabzon (Turkey). Rend. Lincei 2014, 25, 141-153. [CrossRef]

11. Lososova, Z.; Chytry, M.; Kuhn, I.; Hajek, O.; Horakova, V.; Pysek, P.; Tichy, L. Patterns of plant traits in annual vegetation of man-made habitats in Central Europe. Perspect. Plant Ecol. Evol. Syst. 2006, 8, 69-81. [CrossRef]

12. Knapp, S.; Kuhn, I.; Wittig, R.; Ozinga, W.A.; Poschold, P.; Klotz, S. Urbanization causes shifts in species' trait state frequencies. Preslia 2008, 80, 375-388.

13. Thompson, K.; McCarthy, M.A. Traits of British alien and native urban plants. J. Ecol. 2008, 96, 853-859. [CrossRef]

14. Williams, N.S.G.; Schwartz, M.W.; Vesk, P.A.; McCarthy, M.A.; Hahs, A.K.; Clemants, S.E.; Corlett, R.T.; Duncan, R.P.; Norton, B.A.; Thompson, K.; et al. A conceptual framework for predicting the effects of urban environments on floras. J. Ecol. 2009, 97, 4-9. [CrossRef]

15. Lososova, Z.; Lanikova, D. Differences in trait compositions between rocky natural and artificial habitats. J. Veg. Sci. 2010, 21, 520-530. [CrossRef]

16. Jim, C.Y. Old stone walls as an ecological habitat for urban trees in Hong Kong. Landsc. Urban Plan. 1998, 42, 29-43. [CrossRef]

17. Cooper, A. Plant species coexistence in cliff habitats. J. Biogeogr. 1997, 24, 483-494. [CrossRef]

18. Woodell, S. The Floral of Walls and Pavings in Nature in Cities; Laurie, I.C., Ed.; Wiley: Chichester, UK, 1979; pp. 135-157.

19. Larson, D.W.; Matthes, U.; Kelly, P.E.; Lundholm, J.T.; Gerrath, J.A. The Urban Cliff Revolution: New Findings on the Origins and Evolution of Human Habitats; Fitzhenry and Whiteside: Markham, ON, Canada, 2004.

20. Turkish Statistical Institute Printing Division. Address Based Population Registration System Results 2013; Turkish Statistical Institute Printing Division: Ankara, Turky, 2013.

21. Davis, P.H. Flora of Turkey and the East Aegean Islands, vol. 1-9; Aldine Publishing Co.: New York, NY, USA, 1965; Volume 1. 
22. Davis, P.H. Flora of Turkey and the East Aegean Islands, vol. 1-9; Aldine Publishing Co.: New York, NY, USA, 1985; Volume 9.

23. Boissier, P.E. Flora Orientalis Vol. I-V; A. Asher \& Co. B.V.: Amsterdam, The Netherlands, 1975.

24. Raunkiaer, C. The Life Forms of Plants and Statistical Plant Geography; Oxford University Press: London, UK, 1934.

25. Ellenberg, H.; Mueller-Dombois, D. A key to Raunkiaer plant life forms with revised subdivisions. Ber. Geobot. Inst. 1967, 37, 56-73.

26. Evans, J.D. Straightforward Statistics for the Behavioral Sciences; Brooks/Cole Publishing Company: Pacific Grove, CA, USA, 1996.

27. Kramer, S.L. Geotechnical Earthquake Engineering; Prentice Hall Inc.: Upper Saddle River, NJ, USA, 1996.

28. Wee, Y.C. The occurrence of Ficus spp. on high-rise buildings in Singapore. Int. Biodeterior. Biodegrad. 1992, 29, 53-59. [CrossRef]

29. Lesser, L.M. Hardscape damage by tree roots. J. Arboric. 2001, 27, 272-276.

30. McPherson, E.G.; Gonzalez, G.; Monfette, G.; Lorenzen, R. Expanding street tree canopy cover and repairing sidewalks in the city of Los Angeles. West. Arbor. 2003, 22-25.

31. Randrup, T.B.; McPherson, E.G.; Costello, L.R. Are view of tree root conflicts with sidewalks, curbs, and roads. Urban Ecosyst. 2003, 5, 209-225. [CrossRef]

32. Landscape Advice Note: Vegetation on Walls. Available online: http://www.english-heritage.org.uk/ content/learn/conservation/2544404/LAN_-_Vegetation_on_walls.pdf (accessed on 21 February 2016).

33. Lisci, M.; Pacini, E. Plants growing on the walls of Italian towns 1. Sites and distribution. Phyton 1993, 33, 15-26.

34. Lisci, M.; Monte, M.; Pacini, E. Lichens and higher plants on stone: A review. Int. Biodeterior. Biodegrad. 2003, 51, 1-17. [CrossRef]

35. Dos Reis, V.A.; Lombardi, J.A.; de Figueiredo, R.A. Diversity of vascular plants growing on walls of a Brazilian city. Urban Ecosyst. 2006, 9, 39-43. [CrossRef]

36. Manuel, J.S.; Andreas, G.; Christine, M.; Andreas, S.; Carl, B. Quantification of wall surface heterogeneity and its influence on species diversity at medieval castles-Implications for the environmentally friendly preservation of cultural heritage. J. Cult. Herit. 2013, 14, 219-228.

37. Gilbert, O. Rootedin Stone: The Natural Flora of Urban Walls; English Nature: Peterborough, UK, 1992. 